Article

\title{
The Acute Effects of Oral Administration of Phytic Acid-Chitosan-Magnetic Iron Oxide Nanoparticles in Mice
}

\author{
Norain Mohd Tamsir ${ }^{1}{ }^{\mathbb{D}}$, Norhaizan Mohd Esa ${ }^{1,2,3, *}$, Nurul Husna Shafie ${ }^{1,4}(\mathbb{D}$, \\ Mohd Zobir Hussein ${ }^{5}{ }^{(}$, Hazilawati Hamzah ${ }^{6}$ and Maizaton Atmadini Abdullah ${ }^{7}$ (b) \\ 1 Department of Nutrition and Dietetics, Faculty of Medicine and Health Sciences, Universiti Putra Malaysia, \\ 43400 Serdang, Selangor, Malaysia \\ 2 Research Centre of Excellent, Nutrition and Non-Communicable Diseases (NNCD), Faculty of Medicine and \\ Health Sciences, Universiti Putra Malaysia, 43400 Serdang, Selangor, Malaysia \\ 3 Laboratory of Molecular Biomedicine, Institute of Bioscience, Universiti Putra Malaysia, \\ 43400 Serdang, Selangor, Malaysia \\ 4 Laboratory of UPM-MAKNA Cancer Research, Institute of Bioscience, Universiti Putra Malaysia, \\ 43400 Serdang, Selangor, Malaysia \\ 5 Materials Synthesis and Characterization Laboratory, Institute of Advance Technology (ITMA), Universiti \\ Putra Malaysia, 43400 Serdang, Selangor, Malaysia \\ 6 Department of Veterinary Pathology and Microbiology, Faculty of Veterinary Medicine, Universiti Putra \\ Malaysia, 43400 Serdang, Selangor, Malaysia \\ 7 Department of Pathology, Faculty of Medicine and Health Sciences, Universiti Putra Malaysia, \\ 43400 Serdang, Selangor, Malaysia \\ * Correspondence: nhaizan@upm.edu.my; Tel.: +603-89472427
}

Received: 24 June 2019; Accepted: 19 August 2019; Published: 23 August 2019

\begin{abstract}
A nanocomposite, phytic acid-chitosan-magnetic iron oxide nanoparticles ( $\mathrm{IP}_{6}$-CS-MNPs) has been used to treat colon cancer in vitro, previously. However, its potential toxicity in vivo has yet to be elucidated. Hence, the present study aimed to evaluate the acute effects of oral administration of $\mathrm{IP}_{6}$-CS-MNPs in mice. In this study, 1000 and $2000 \mathrm{mg} / \mathrm{kg}$ body weight (b.w) of $\mathrm{IP}_{6}$-CS-MNPs were orally administered to two different groups of BALB/c mice, once. Additionally, the mice in the control group were given only deionized water. After 14 days of post-IP ${ }_{6}$-CS-MNPs administration, in a similar way to the untreated mice, the treated mice showed no sign of mortality and abnormalities. However, the serum urea level of mice receiving $2000 \mathrm{mg} / \mathrm{kg}$ b.w of $\mathrm{IP}_{6}$-CS-MNPs was significantly higher than the control group $(p<0.05)$. The mice that received $1000 \mathrm{mg} / \mathrm{kg} \mathrm{IP}{ }_{6}$-CS-MNPs showed a significantly higher level of serum alkaline phosphatase (ALP) compared to the control group. However, there were no significant histopathological changes seen in the liver and kidneys of treated mice compared to the untreated group.
\end{abstract}

Keywords: inositol hexaphosphate; magnetic nanoparticles; nanotoxicology; polymer-based nanocomposite

\section{Introduction}

Nanotechnology application in biomedicine has revolutionized dynamically. It has triggered a plethora of new magnetic iron oxide nanoparticles' (MNPs) formulations and productions. Based on contrast enhancement agent in imaging, MNPs are now widely used in disease treatment due to its unique properties including biocompatibility, stability, being environmentally safe, as well as cheaply produced [1,2]. Nonetheless, MNPs have low solubility and tend to agglomerate due to the attraction to each other by groups of hydroxyl. This will subsequently increase the size of the nanoparticles and 
obstruct blood vessels [3]. Chemical co-precipitation is commonly used to synthesize MNPs because it is convenient and cost-effective [4]. This method of synthesis results in spherical shape and small size of nanoparticles [5]. There are several factors that may interfere with the magnetic properties, particles size, as well as the shape of MNPs via the co-precipitation method. Such factors may include the $\mathrm{Fe}^{2+}$ (ferrous) $/ \mathrm{Fe}^{3+}$ (ferric) ratio, reaction temperature, the order of reactants' addition, and the use of dispersing agent, [6] which usually results in nanoparticle agglomeration [7]. It has been revealed that the modification of MNPs' surface by polymers such as chitosan enhances the instability between particles and prevents agglomeration [8].

Natural and synthetic biodegradable polymers as nanocarriers have been expansively applied in nanomedicine. They function as controlled release vehicles for various drugs, agents, peptides, proteins, etc. [9]. Polymer-based nanoparticles are less toxic and deliver efficiently [10]. They are also able to distinguish between cancer and healthy tissues and may help curb multidrug resistance [11]. That being said, chitosan has been considered as one of the best natural polymer-based carriers for the MNPs drug delivery system. Chitosan is a biodegradable and biocompatible polymer, derived from the chitin of fungi and crustacean shells. It exhibits distinctive biological activities such as antioxidant, anti-fungal, antibacterial, and anti-tumor [12]. The positive charge of chitosan also drives it to the negatively-charged cell membrane. Additionally, its mucoadhesive behavior prolongs the duration of blood circulation [13].

Conventional chemotherapy is considered effective. However, selective chemotherapeutic agents are known to have caused adverse effects, multiple drug resistance, and sometimes off-target actions [14]. Therefore, several approaches have been introduced to minimize the side effects and maneuver the actions of the drugs or agents towards the periphery of the targeted site. Phytic acid is a naturally occurring chemotherapeutic agent, which has been extensively studied for pharmacological properties. Phytic acid possesses a $\mathrm{C}_{6} \mathrm{H}_{18} \mathrm{O}_{24} \mathrm{P}_{6}$ (Figure 1) chemical formula known as inositol hexaphosphate $\left(\mathrm{IP}_{6}\right)$. Inositol hexaphosphate is a saturated cyclic, which is ubiquitously found in the plant tissues and acts as storage forms of phosphorus in mammalian cells. $\mathrm{IP}_{6}$ in bran is abundantly found as a by-product of the rice-milling industry in Malaysia where rice is the staple food. $\mathrm{IP}_{6}$ has been found to have significant antioxidant [15] and anti-cancerous properties in different cell lines [16-18] as well as in in vivo models [19].

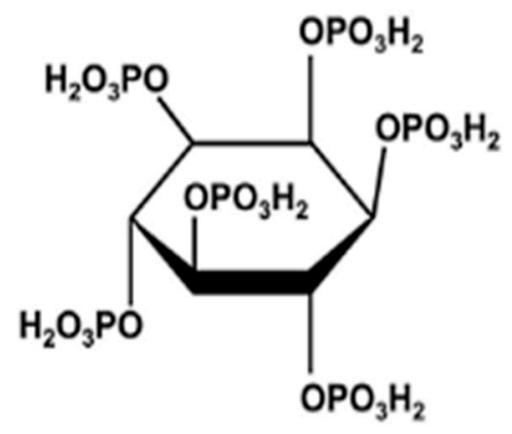

Figure 1. Molecular structure of phytic acid (Source: Higuchi et al., 2014) [20].

In 2017, Barahuie et al. [21] synthesized a phytic acid-chitosan-magnetic iron oxide nanocomposite (IP 6 -CS-MNPs) and found that it was not toxic to the normal cells (3T3 fibroblast cells). A recent work by Tan and colleagues [22] showed that $\mathrm{IP}_{6}$-CS-MNPs induced cell cycle arrest at $\mathrm{G}_{0} / \mathrm{G}_{1}$ phase and apoptosis in colorectal cancer cell lines. This proved that the nanocomposite is a potential anticancer agent. However, animal studies should be conducted before clinical studies to examine the potentially toxic effect of the newly-developed nanocomposite in a more complex system, which mimics human reactions. Therefore, the present study was designed to elucidate the acute oral toxicity of the $\mathrm{IP}_{6}$-CS-MNPs nanocomposite in mice. 


\section{Results}

\subsection{Animal Observation, Mortality, and Body Weight Change}

An acute toxicity study using 18 female Balb/c mice (6-8 weeks) was conducted with an oral administration of 1000 and $2000 \mathrm{mg} / \mathrm{kg}$ body weight (b.w) of $\mathrm{IP}_{6}$-CS-MNPs (in $0.5 \mathrm{~mL}$ deionized water) to two different treatment groups, respectively. Another group (control group) received only deionized water $(0.5 \mathrm{~mL})$. The first group (controlled group) was only given $0.5 \mathrm{~mL}$ of deionized water. For 14 days the mice did not exhibit behavioral toxicity symptoms such as bleeding, vomiting, abnormal posture, diarrhea, irritation, breathing difficulties, restlessness, and mortality, despite being treated with 1000 or $2000 \mathrm{mg} / \mathrm{kg}$ of b.w of $\mathrm{IP}_{6}$-CS-MNPs. Therefore, the results proved that the median lethal dose $\left(\mathrm{LD}_{50}\right)$ of $\mathrm{IP}_{6}$-CS-MNPs was greater than $2000 \mathrm{mg} / \mathrm{kg}$ of b.w. The body weight of the mice in the controlled and treatment group pre-experiment, and on the 7 th and 14 th day of post-experiment was recorded (Table 1). The body weight of the mice in the first week of the post-nanocomposite administration resulted in a slight decline. Nevertheless, after 2 weeks, the mice demonstrated slight weight gain.

Table 1. Effect of phytic acid-chitosan-magnetic iron oxide nanoparticles (IP ${ }_{6}$-CS-MNPs) on mouse body weight.

\begin{tabular}{cccc}
\hline \multirow{2}{*}{ Day } & \multicolumn{2}{c}{ Body Weight (g) } \\
\cline { 2 - 4 } & Control & $\mathbf{1 0 0 0 ~} \mathbf{~ g /} / \mathbf{k g}$ & $\mathbf{2 0 0 0} \mathbf{~} \mathbf{g} / \mathbf{k g}$ \\
\hline 0 & $18.94 \pm 0.55^{\mathrm{a}}$ & $18.07 \pm 0.44^{\mathrm{a}}$ & $18.69 \pm 0.45^{\mathrm{a}}$ \\
7 & $18.61 \pm 0.54^{\mathrm{a}}$ & $17.88 \pm 0.40^{\mathrm{a}}$ & $18.59 \pm 0.44^{\mathrm{a}}$ \\
14 & $19.2 \pm 0.52^{\mathrm{a}}$ & $18.48 \pm 0.30^{\mathrm{a}}$ & $19.15 \pm 0.47^{\mathrm{a}}$ \\
\hline
\end{tabular}

All values represent the mean \pm standard error of mean (SEM). ${ }^{\text {a }}$ Values in the same row with the similar superscript letter were not significantly different.

\subsection{Relative Organ Weight}

The weight of mice organs (liver, kidney, spleen, brain, heart, colon, and lungs) from all groups of mice were used to calculate the relative organ's weight. The results are recorded in Table 2. There was no significant difference in the relative organ's weight between controlled and treatment groups $(p>0.05)$ on the 14 th day of exposure to 1000 or $2000 \mathrm{mg} / \mathrm{kg}$ b.w of $\mathrm{IP}_{6}$-CS-MNPs.

Table 2. Effects of $\mathrm{IP}_{6}$-CS-MNPs on relative organ weight.

\begin{tabular}{cccc}
\hline \multirow{2}{*}{ Organ } & \multicolumn{3}{c}{ Relative Organ Weight } \\
\cline { 2 - 4 } & Control & $\mathbf{1 0 0 0} \mathbf{~} \mathbf{~ g} / \mathbf{k g}$ & $\mathbf{2 0 0 0} \mathbf{~} \mathbf{g} / \mathbf{k g}$ \\
\hline Liver & $4.32 \pm 0.25^{\mathrm{a}}$ & $4.51 \pm 0.38^{\mathrm{a}}$ & $4.60 \pm 0.19^{\mathrm{a}}$ \\
Kidney & $0.64 \pm 0.02^{\mathrm{a}}$ & $0.65 \pm 0.04^{\mathrm{a}}$ & $0.57 \pm 0.03^{\mathrm{a}}$ \\
Heart & $0.71 \pm 0.11^{\mathrm{a}}$ & $0.52 \pm 0.03^{\mathrm{a}}$ & $0.53 \pm 0.04^{\mathrm{a}}$ \\
Lung & $0.69 \pm 0.05^{\mathrm{a}}$ & $0.72 \pm 0.10^{\mathrm{a}}$ & $0.92 \pm 0.11^{\mathrm{a}}$ \\
Spleen & $0.42 \pm 0.10^{\mathrm{a}}$ & $0.31 \pm 0.03^{\mathrm{a}}$ & $0.38 \pm 0.05^{\mathrm{a}}$ \\
Brain & $2.18 \pm 0.08^{\mathrm{a}}$ & $2.26 \pm 0.05^{\mathrm{a}}$ & $2.05 \pm 0.52^{\mathrm{a}}$ \\
Colon & $1.80 \pm 0.26^{\mathrm{a}}$ & $2.94 \pm 0.89^{\mathrm{a}}$ & $2.13 \pm 0.15^{\mathrm{a}}$
\end{tabular}

All values represent the mean \pm SEM. ${ }^{a}$ Values in the same row with similar superscript were not significantly different $(p>0.05)$.

\subsection{Biochemical Analysis}

Table 3 shows the biochemical test results obtained from mice serum after 14 days of $\mathrm{IP}_{6}$-CS-MNPs treatment. Liver enzymes such as alkaline phosphatase (ALP), aspartate aminotransferase (AST), and alanine transferase (ALT) were measured to assess the liver function whereas creatinine and urea were measured to evaluate kidney function. There was an imperative higher level of ALP in $1000 \mathrm{mg} / \mathrm{kg}$ b.w $\mathrm{IP}_{6}$-CS-MNPs-treated group compared to the other groups $(p<0.05)$. The serum urea level of mice 
treated with $2000 \mathrm{mg} / \mathrm{kg}$ of $\mathrm{IP}_{6}$-CS-MNPs was significantly higher $(p<0.05)$ than the controlled group and $1000 \mathrm{mg} / \mathrm{kg}$ of $\mathrm{IP}_{6}$-CS-MNPs. Nevertheless, the level of serum AST, ALT, and creatinine showed no significant difference between groups $(p>0.05)$.

Table 3. Effects of $\mathrm{IP}_{6}$-CS-MNPs on liver and kidney biochemical parameters.

\begin{tabular}{|c|c|c|c|}
\hline Parameter & Control & $1000 \mathrm{mg} / \mathrm{kg} \mathrm{b.w}$ & $2000 \mathrm{mg} / \mathrm{kg} \mathrm{b.w}$ \\
\hline $\operatorname{ALP}(\mathrm{U} / \mathrm{L})$ & $117.3 \pm 5.68^{a}$ & $159.33 \pm 6.73^{b}$ & $132.33 \pm 6.51^{a}$ \\
\hline AST (U/L) & $113.83 \pm 20.46^{\mathrm{a}}$ & $111.50 \pm 13.60^{a}$ & $157.00 \pm 26.10^{\mathrm{a}}$ \\
\hline $\operatorname{ALT}(\mathrm{U} / \mathrm{L})$ & $23.67 \pm 5.10^{\mathrm{a}}$ & $18.67 \pm 2.36^{a}$ & $20.17 \pm 2.29^{a}$ \\
\hline Creat $(\mu \mathrm{mol} / \mathrm{L})$ & $30.00 \pm 1.21^{\mathrm{a}}$ & $30.00 \pm 0.82^{a}$ & $31.67 \pm 1.33^{a}$ \\
\hline Urea (mmol/L) & $8.02 \pm 0.43^{\mathrm{a}}$ & $7.67 \pm 0.26^{\mathrm{a}}$ & $9.75 \pm 0.48^{b}$ \\
\hline
\end{tabular}

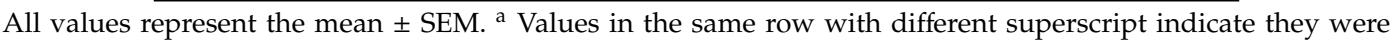
significantly different $(p<0.05)$. ALP—alkaline phosphatase; AST—aspartate aminotransferase; ALT—alanine aminotransferase; Creat—creatinine.

\subsection{Histopathological Evaluation}

Toxicological lesions in the liver such as inflammation, necrosis, and regeneration were examined and scored. Figure 2 proved that the histopathological examination on the livers of treated mice revealed no remarkable lesions that could be attributed to the effect of 1000 or $2000 \mathrm{mg} / \mathrm{kg} \mathrm{b.w}$ of $\mathrm{IP}_{6}$-CS-MNPs (Figure 2).

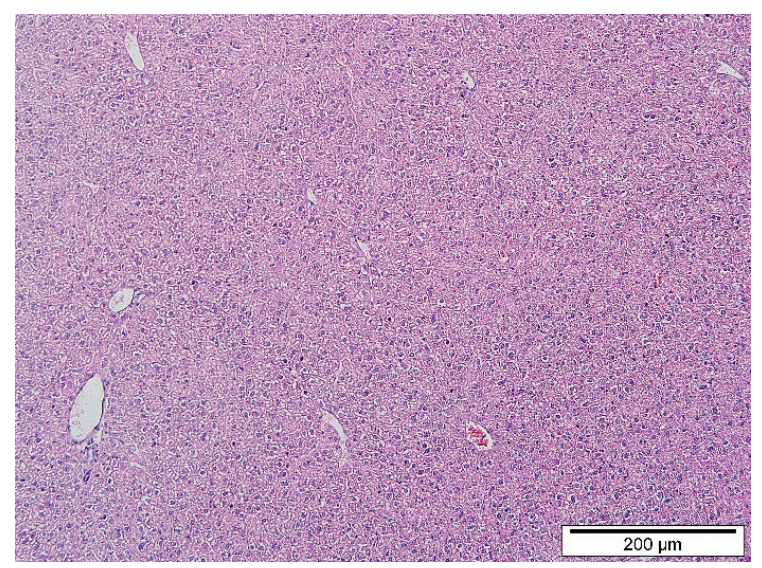

(a)

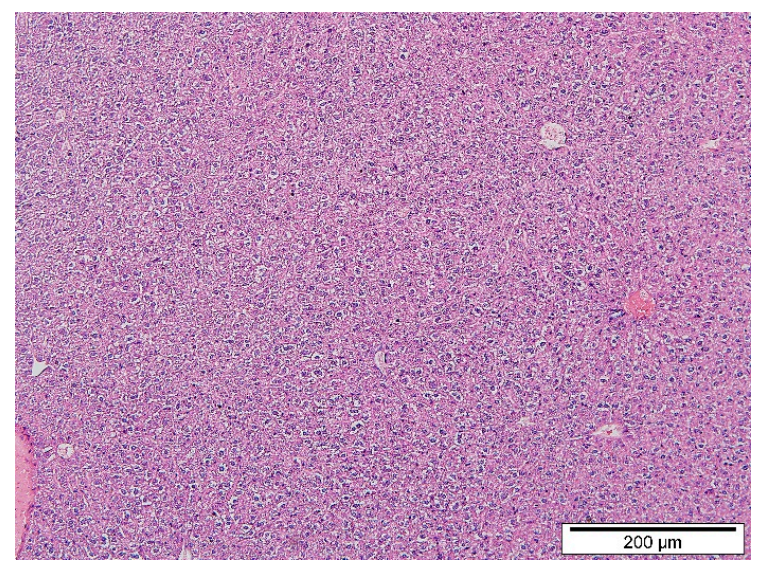

(b)

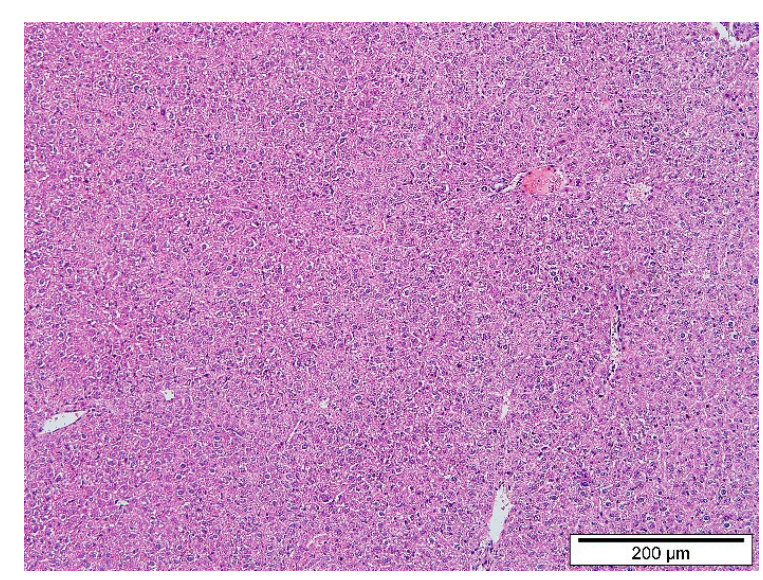

(c)

Figure 2. Liver section of: (a) control group of mice that received only deionized water; (b) $1000 \mathrm{mg} / \mathrm{kg}$ of $\mathrm{IP}_{6}$-CS-MNPs; (c) $2000 \mathrm{mg} / \mathrm{kg}$ of $\mathrm{IP}_{6}$-CS-MNPs (hematoxylin and eosin (H\&E) stain, $\times 100$ ). 
Besides that, the toxicological lesions in the kidney tissues such as inflammation, cellular cast, granular cast, protein cast, hydropic degeneration, and necrosis were examined and scored. Additionally, there were no histopathological changes observed in the kidney tissues (Figure 3). Therefore, both histopathological scorings of kidney and liver showed no remarkable lesions that could be attributed to the effect of 1000 and $2000 \mathrm{mg} / \mathrm{kg}$ b.w of $\mathrm{IP}_{6}$-CS-MNPs administration.

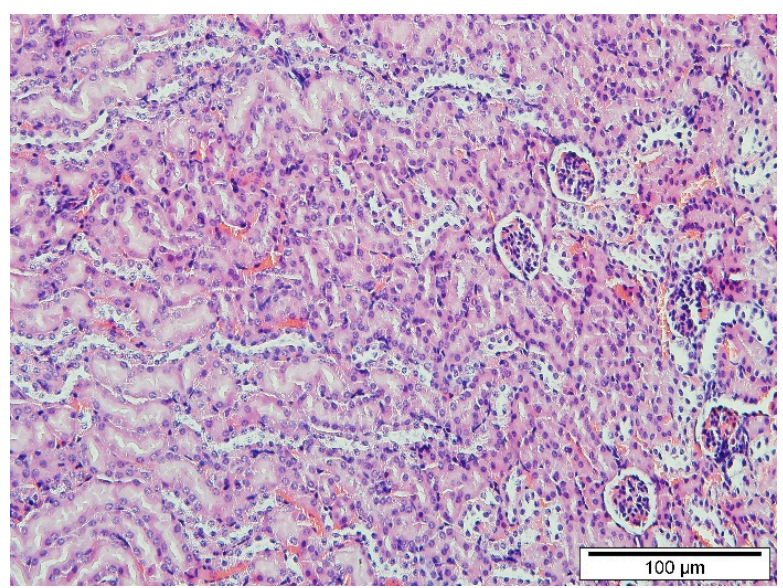

(a)

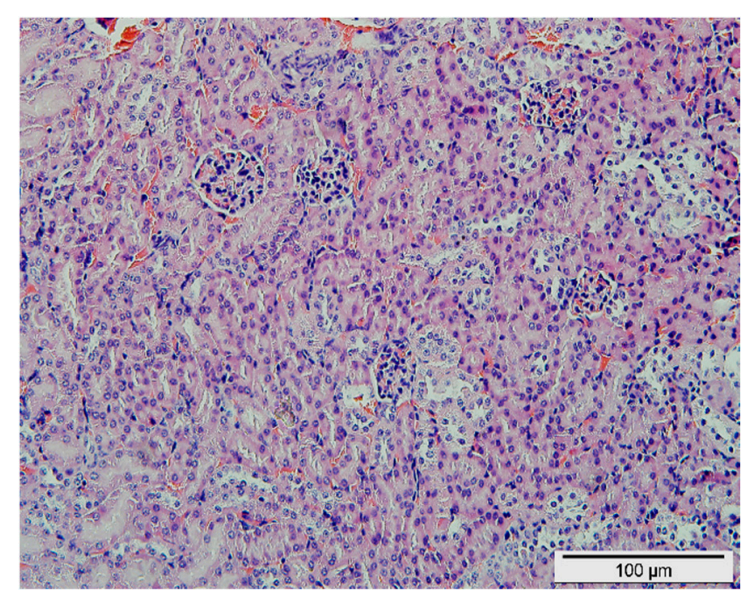

(b)

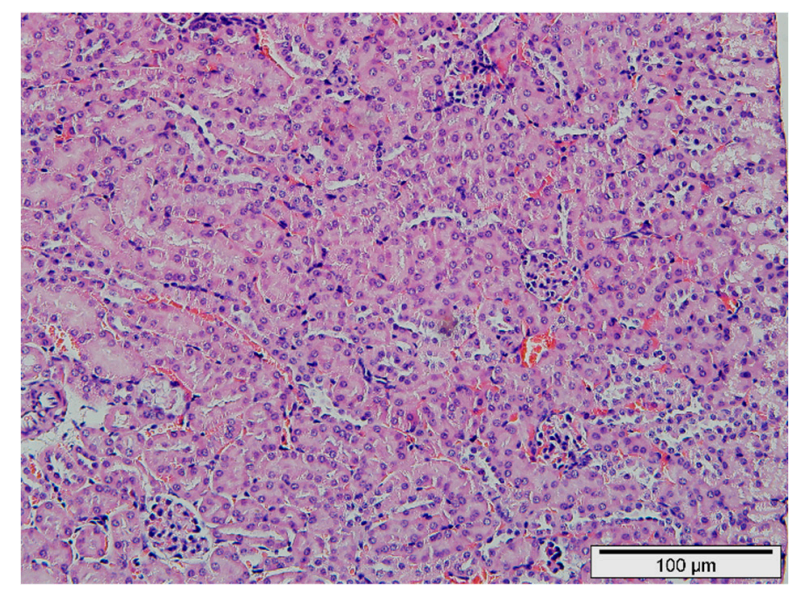

(c)

Figure 3. Kidney section of: (a) control group of mice that received only deionized water; (b) $1000 \mathrm{mg} / \mathrm{kg}$ of $\mathrm{IP}_{6}$-CS-MNPs; (c) $2000 \mathrm{mg} / \mathrm{kg}$ of $\mathrm{IP}_{6}$-CS-MNPs (H\&E stain, $\times 100$ ).

\section{Discussion}

Nanoparticles vary in shape and size. Hence, our previous study focused on the characterization of MNPs to prove that they were spherical with an average size of $15 \pm 6 \mathrm{~nm}$ [21]. Due to their tiny size, studies on their toxicity effects are crucial. Therefore, acute toxicity studies have been conducted on experimental animals and humans to evaluate the effects of single high dose and divided doses of test substances via multiple routes of administration in a short period of time [23]. This was evaluated based on several signs and symptoms such as abnormal posture or behavior and episodes of seizures. According to the Organization for Economic Co-operation and Development (OECD), it is imperative to observe the mortality rate, specifically the median lethal dose $\left(\mathrm{LD}_{50}\right)$ as it is significant for the acute toxicity evaluation [24]. Previous work has claimed that the $\mathrm{LD}_{50}$ of uncoated iron oxide nanoparticles was 300-600 mg Fe/kg b.w [25]. Meanwhile, the current study discovered that there were no signs of 
toxicity and mortality throughout the experiment. Therefore, it can be suggested that the $\mathrm{IP}_{6}$-CS-MNPs $\mathrm{LD}_{50}$ is greater than $2000 \mathrm{mg} / \mathrm{kg}$ b.w.

Changes in experimental animals' body weights could also be an important marker to evaluate their health status. Therefore, a loss of $10 \%$ or more of body weight in comparison to the initial body weight signals unwanted effects of the chemical substances [26]. The present study revealed a pattern in the weight of the mice from both groups. In the beginning, there was an insignificant decrease however, and it soon increased until the end of the experiment $(p>0.05)$. These changes in weight are concordant to a study conducted by Monika et al. [27]. Hence, the loss in body weight is related to the body's normal physiological response as it gets adjusted to the exposure of chemical substances. This might be due to the decrease of food or water intake (appetite suppression), which alters the taste or odor of the orally administered $\mathrm{IP}_{6}$-CS-MNPs [28] or damage of major organs such as the stomach, intestine, kidneys, and liver [29].

Toxicity can also be detected based on the weight of the internal organs. In the present experiment, the internal organs' weight including liver, kidneys, brain, lungs, spleen, and heart were measured and compared to the animal's final body weight. Metabolic reactions caused by test drugs or chemicals may affect major internal organ weights. For example, an increase in the weight of the liver may indicate signs of hepatic hypertrophy, which is stimulated by hepatic enzymes [30]. Nevertheless, findings proved no significant changes in the relative organ weight. Therefore, it is possible that the nanocomposite may not elicit any deleterious effects on the organs of the mice.

In the study of toxicology, various blood analyses have been used to measure organ and cell damage, as well as the activation or inhibition of certain enzymes. Moreover, it is crucial to evaluate the liver and kidneys when it comes to the process of assessing the levels of toxicity in drugs or chemicals because they play a vital role in metabolic detoxification and excretion. For the liver, the level of certain enzymes such as alanine aminotransferase (ALT), alkaline phosphatase (ALP), and aspartate aminotransferase (AST) contained in the serum should be measured. According to Mahmudul et al. the reference range of ALP is between 30 and $130 \mathrm{IU} / \mathrm{L}$, AST is between 50 and $150 \mathrm{IU} / \mathrm{L}$, and ALT is between 10 and $40 \mathrm{IU} / \mathrm{L}$ [31]. The results showed a substantial increase in the ALP serum in treating the mice with $1000 \mathrm{mg} / \mathrm{kg}$ b.w of $\mathrm{IP}_{6}$-CS-MNPs $(p<0.05)$. Elevated reading of the ALP enzyme might be attributed to many reasons. Besides that, the ALP enzyme is also found in other tissues such as the bone, kidney, intestine, and placenta. Furthermore, the ALP level can help detect hepatobiliary diseases, osteoporosis, and fatty liver disease. [32]. The accumulation of ALP in serum from liver, bone, kidney, and intestine might result in the elevation of this enzyme. That being said, the long-term effects following the consumption of $\mathrm{IP}_{6}$-CS-MNPs needs further investigation.

Additionally, the levels of creatinine and urea in the serum can detect certain abnormalities in the kidneys. Results prove that the serum creatinine in the control and treated groups of mice did not show any significant difference. However, there was an increase in the level of serum urea in the group of mice treated with $2000 \mathrm{mg} / \mathrm{kg}$ b.w of $\mathrm{IP}_{6}$-CS-MNPs $(p<0.05)$ compared to the control group. Urea is the major nitrogenous waste product of metabolism and is generated from protein degradation in the body. According to the previous study, if the level of creatinine is normal but the level of urea in the blood has increased, then it might be due to dehydration, which results in reduced blood flow to kidneys, gastrointestinal bleeding, or high protein intake [33].

The histopathological assessments of both organs provide supportive evidence for biochemical analyses. The present study work revealed no significant abnormalities or lesions were seen in both liver and kidneys of $\mathrm{IP}_{6}$-CS-MNPs treated and control groups. In the future, it would be of great significance if studies may look at the $\mathrm{IP}_{6}$-CS-MNPs cell tissue and their potential neurotoxicity effects. 


\section{Materials and Methods}

\subsection{Chemicals and Reagents}

Iron (III) chloride hexahydrate $\left(\mathrm{FeCl}_{3} \cdot 4 \mathrm{H}_{2} \mathrm{O},>99.8 \%\right.$ purity) and iron (II) chloride tetrahydrate $\left(\mathrm{FeCl}_{2} \cdot 6 \mathrm{H}_{2} \mathrm{O}\right)$ were acquired from Merck KGaA (Darmstadt, Germany). Phytic acid sodium salt hydrate with a molecular weight of $660.04 \mathrm{kDa}$ and chitosan were purchased from Sigma-Aldrich (St. Louis, MO, USA). Ammonia was supplied from Scharlau (Sentmenat, Barcelona, Spain). Acetic acid was obtained from Hamburg Industries (Hamburg, Germany).

\subsection{Magnetic Iron Oxide Nanoparticle Synthesis}

The MNPs were prepared via chemical precipitation based on the method suggested by Barahuie et al. [21]. Initially, the mixture was made up of $2.43 \mathrm{~g}$ ferric chloride hexahydrate $\left(\mathrm{FeCl}_{3} \cdot 4 \mathrm{H}_{2} \mathrm{O}\right)$, $0.99 \mathrm{~g}$ of ferrous chloride tetrahydrate $\left(\mathrm{FeCl}_{2} \cdot 6 \mathrm{H}_{2} \mathrm{O}\right)$, and $80 \mathrm{~mL}$ of deionized water. Then it was topped with $6 \mathrm{~mL}$ drops of $25 \%$ ammonia. The mixture was maintained at a $\mathrm{pH}$ value of 10 . Then, the mixture was sonicated for an hour at room temperature. Next, the mixture was centrifuged, and the obtained magnetic nanoparticles were repeatedly washed with deionized water to eliminate the traces of ammonia. The obtained magnetic nanoparticles $\left(\mathrm{Fe}_{3} \mathrm{O}_{4}\right)$ were dried in the oven at $60{ }^{\circ} \mathrm{C}$ and grounded into powder for further characterization and analysis.

\subsection{Coating of Magnetic Iron Oxide Nanoparticles with Chitosan}

Approximately, $1 \mathrm{~g}$ of chitosan was dissolved in deionized water with $0.5 \%$ acetic acid and stirred for $3 \mathrm{~h}$. The chitosan solution was then added to the MNPs suspension and stirred with a rotational speed of $600 \mathrm{rpm}$ for $18 \mathrm{~h}$ at room temperature. The mixture was centrifuged and repeatedly washed with deionized water to remove traces of ammonia [34]. The product was then labeled as CS-MNPs.

\subsection{Phytic Acid-Chitosan-Iron Oxide Nanocomposite Synthesis}

Next, $2 \%$ of the phytic acid solution was added to the CS-MNPs. The mixture was vigorously stirred for $24 \mathrm{~h}$. Finally, the mixture (labeled as $\mathrm{IP}_{6}$-CS-MNPs) was centrifuged, washed, and dried in the oven at $60{ }^{\circ} \mathrm{C}[21]$.

\subsection{Experimental Animals and Grouping}

A total of 18 female, Balb/c mice (6-7 weeks old) with an average weight of 18-20 g were obtained from Animal Resource, Faculty of Veterinary Medicine, Universiti Putra Malaysia (UPM), Serdang, Selangor. The procedures of mice treating were approved by the Institutional of Animal Care and Use Committee (IACUC), UPM. Its reference number was UPM/IACUC/AUP-R030/2016. Prior to the treatment, all animals were acclimatized for a week and were provided free access to standard mouse pellets and water. Animals were maintained under standard laboratory conditions. For example, the were kept under a 12-h light/dark cycle at a temperature of $25 \pm 2{ }^{\circ} \mathrm{C}$ and in relative humidity between $30 \%$ and $70 \%$. The mice were then randomly divided into three groups post-acclimatization (Table 4). On day one, the mice were given either deionized water or $\mathrm{IP}_{6}-\mathrm{CS}-\mathrm{MNPs}$ via oral gavage. The $\mathrm{IP}_{6}$-CS-MNPs suspensions were sonicated before they were given to the mice in the treatment group.

Table 4. Animal grouping.

\begin{tabular}{ccc}
\hline Groups & Dosage & Number of Mice \\
\hline 1 & $1 \mathrm{~mL}$ deionized water & 6 \\
2 & $1000 \mathrm{mg} / \mathrm{kg}$ b.w of $\mathrm{IP}_{6}$-CS-MNPs & 6 \\
3 & $2000 \mathrm{mg} / \mathrm{kg} \mathrm{b.w} \mathrm{of} \mathrm{IP}_{6}$-CS-MNPs & 6 \\
\hline
\end{tabular}




\subsection{Animal Observation}

The animals were observed for any clinical signs of toxicity or possible mortality within the first $30 \mathrm{~min}$, periodically within the first $24 \mathrm{~h}$ post-dosing and thereafter, daily for a total of 14 days. The body weight of the mice was measured before nanocomposite administration and weekly thereafter.

\subsection{Serum Collection}

On the 15th day the mice were euthanized via exsanguination under ketamine $(80 \mathrm{mg} / \mathrm{kg})$ and xylazine $(10 \mathrm{mg} / \mathrm{kg})$ mixture. Prior to the euthanasia, the mice were allowed to fast for 3-4 h. Blood samples were then collected via cardiac puncture. The study used a 26-gauge needle and a $1 \mathrm{~mL}$ syringe under anesthesia which was stored in ice before serum separation. Serum samples were collected after centrifugation at a speed of $3000 \mathrm{rpm}$ at $4{ }^{\circ} \mathrm{C}$ for $15 \mathrm{~min}$. The samples were then kept at $-20^{\circ} \mathrm{C}$ until serum biochemistry analysis was conducted.

\subsection{Serum Biochemistry Analysis}

The collected serum samples measured the levels of ALT, AST, and ALP to detect hepatotoxicity, urea, and creatinine for the evaluation of nephrotoxicity. The tests were done via the automated biochemistry analyzer (Tokyo Boeki Machinery Ltd., Japan).

\subsection{Organ Collection}

Post mortem examination was done instantaneously after the sacrifice to identify abnormalities on the animals' vital organs. Vital organs such as the liver, kidney, heart, lung, brain, spleen, and colon were harvested and washed with normal saline. They were then weighed to calculate the relative organ weight. The algorithm is as follows: relative organ weight $=$ (organ weight/ body weight $) \times 100$.

\subsection{Histopathological Assessment}

The livers and kidneys were fixed in neutral-buffered formalin and were embedded in paraffin wax for the histopathological analysis. After cooling, the paraffin blocks were divided into sections with $5 \mu \mathrm{m}$ of thickness, which was mounted onto glass slides, deparaffinized, and stained by hematoxylin and eosin (H\&E). Slides were viewed under a light microscope to observe abnormalities. Besides that, the light microscope was able to score the liver and kidney tissues to determine the changes that occurred in the experimentally-induced histopathologic parameters.

\subsection{Statistical Analysis}

The experiments were expressed as the mean and standard error of mean (SEM) values for each group. The data were analyzed using the one-way analysis of variance (ANOVA) with Tukey's test to evaluate the differences between groups. Statistical analyses were performed by IBM SPSS Statistics, Software version 25 (SPSS Inc., Chicago, IL, USA). As a result, $p<0.05$ was considered to be significantly different.

\section{Conclusions}

We conclude that the $\mathrm{LD}_{50}$ of the $\mathrm{IP}_{6}$-CS-MNPs is greater than $2000 \mathrm{mg} / \mathrm{kg}$ of b.w and caused a slight biochemical alteration after oral administration. Nevertheless, there were no mortality and histopathological changes seen. Further investigations of the chronic toxicity and biodistribution should be conducted for a detailed safety profile on $\mathrm{IP}_{6}-\mathrm{CS}-\mathrm{MNPs}$.

Author Contributions: Conceptualization, N.M.E., N.H.S., and M.Z.H.; Methodology, N.M.T., N.M.E., and M.Z.H.; Supervision, N.M.E.; Validation, H.H. and M.A.A.; Writing-original draft, N.M.T.; Writing-review and editing, N.M.E., N.H.S., H.H., and M.A.A.

Funding: This research was funded by Universiti Putra Malaysia (Project code: GP-IPS/2016/9509600).

Acknowledgments: N.M.T. acknowledge the Ministry of Higher Education Malaysia for MyPhD scholarship under the MyBrain15 programme. 
Conflicts of Interest: The authors declare no conflict of interest

\section{Abbreviations}

$\begin{array}{ll}\text { ALP } & \text { Alkaline phosphatase } \\ \text { ALT } & \text { Alanine aminotransferase } \\ \text { AST } & \text { Aspartate aminotransferase } \\ \text { b.w } & \text { Body weight } \\ \text { creat } & \text { Creatinine } \\ \text { CS } & \text { Chitosan } \\ \text { H\&E } & \text { Hematoxylin and eosin } \\ \mathrm{IP}_{6} & \text { Phytic acid } \\ \mathrm{IP}_{6} \text {-CS-MNPs } & \text { Phytic acid-chitosan-magnetic iron oxide nanoparticles } \\ \mathrm{IU}_{\text {L }} & \text { International units per liter } \\ \text { MNPs } & \text { Magnetic iron oxide nanoparticles }\end{array}$

\section{References}

1. Markides, H.; Rotherham, M.A. Biocompatibility and toxicity of magnetic nanoparticles in regenerative medicine. J. Nanomater. 2012, 2012, 13-15. [CrossRef]

2. $\mathrm{Xu}$, J.; Zhang, F.; Sun, J.; Sheng, J.; Wang, F.; Sun, M. Bio and nanomaterials based on $\mathrm{Fe}_{3} \mathrm{O}_{4}$. Molecules 2014, 19, 21506-21528. [CrossRef] [PubMed]

3. Thorat, N.D.; Bohara, R.A.; Malgras, V.; Tofail, S.A.M.; Ahamad, T.; Alshehri, S.M.; Wu, K.C.; Yamauchi, Y. Multimodal superparamagnetic nanoparticles with unusually enhanced specific absorption rate for synergetic cancer therapeutics and magnetic resonance imaging. Appl. Mater. Interfaces 2016, 8, 14656-14664. [CrossRef] [PubMed]

4. Ali, A.; Zafar, H.; Zia, M.; Ul-haq, I.; Phull, A.R.; Ali, J.S.; Hussain, A. Synthesis, characterisation, applications, and challenges of iron oxide nanoparticles. Nanotechnol. Sci. Appl. 2016, 9, 49-67. [CrossRef] [PubMed]

5. Reza, R.T.; Pérez, C.A.M.; Martínez, A.M.; García-casillas, P.E.; De Ingeniería, I.; Autónoma, U.; Juárez, D.C.; Charro, A.; Chihuahua, C.J. Magnetite particle size dependence on the coprecipitation synthesis method for protein separation. NSTI-Nanotech 2010, 1, 534-538.

6. Unsoy, G.; Gunduz, U.; Oprea, O.; Ficai, D.; Sonmez, M.; Radulescu, M.; Alexia, M.; Ficai, A. Magnetite: From synthesis to applications. Curr. Top. Med. Chem. 2015, 15, 1622-1640. [CrossRef]

7. Predescu, A.M.; Matei, E.; Berbecaru, C.; Pantilimon, C.; Vidu, R.; Predescu, C.; Kuncser, V. Synthesis and characterization of dextran-coated iron oxide nanoparticles. R. Soc. Open Sci. 2018, 5, 1-11. [CrossRef]

8. Petcharoen, K.; Sirivat, A. Synthesis and characterization of magnetite nanoparticles via the chemical co-precipitation method. Mater. Sci. Eng. B 2012, 177, 421-427. [CrossRef]

9. William, T.; Menon, J. A review of malaria research in Malaysia. Med. J. Malays. 2014, 69, 82-87.

10. Han, J.; Zhao, D.; Li, D.; Wang, X.; Jin, Z.; Zhao, K. Polymer-based nanomaterials and applications for vaccines and drugs. Polymers 2018, 10,31. [CrossRef]

11. Jabir, N.R.; Tabrez, S.; Ashraf, G.M.; Shakil, S.; Damanhouri, G.A.; Kamal, M.A. Nanotechnology-based approaches in anticancer research. Int. J. Nanomed. 2012, 7, 4391-4408.

12. Kim, S. Competitive biological activities of chitosan and its derivatives: Antimicrobial, antioxidant, anticancer, and anti-inflammatory activities. Int. J. Polym. Sci. 2018, 2018, 13. [CrossRef]

13. Salomao Arias, L.; Pessan, J.P.; Viera, A.P.M.; Maria Toito de Lima, T.; Carlos Botazza Delbem, A.; Roberto Monteiro, D. Iron oxide nanoparticles for biomedical applications: A perspective on synthesis, drugs, antimicrobial activity and toxicity. Antibiotics 2018, 7, 1-32.

14. Mitry, M.A.; Edwards, J.G. Doxorubicin induced heart failure: Phenotype and molecular mechanisms. IJC Hear. Vasc. 2016, 10, 17-24. [CrossRef] [PubMed]

15. Norhaizan, M.E.; Ng, S.K.; Norashareena, M.S.; Abdah, M.A. Antioxidant and cytotoxicity effect of rice bran phytic acid as an anticancer agent on ovarian, breast and liver cancer cell lines. Malays. J. Nutr. 2011, 17, 367-375. [PubMed]

16. Shafie, N.H.; Esa, N.M.; Ithnin, H.; Saad, N.; Pandurangan, A.K. Pro-apoptotic effect of rice bran Inositol Hexaphosphate $\left(\mathrm{IP}_{6}\right)$ on HT-29 colorectal cancer cells. Int. J. Mol. Sci. 2013, 14, 23545-23558. [CrossRef] 
17. Kapral, M.; Wawszczyk, J.; Jesse, K.; Paul-Samojedny, M.; Kúsmierz, D.; Wȩglarz, L. Inositol hexaphosphate inhibits proliferation and induces apoptosis of colon cancer cells by suppressing the AKT/mTOR signaling pathway. Molecules 2017, 22, 1657. [CrossRef]

18. Norazalina, S.; Norhaizan, M.E.; Hairuszah, I.; Sabariah, A.R.; Husna, S.N.; Norsharina, I. Antiproliferation and apoptosis induction of phytic acid in hepatocellular carcinoma $\left(\mathrm{HEPG}_{2}\right)$ cell lines. Afr. J. Biotechnol. 2011, 10, 16646-16653. [CrossRef]

19. Shafie, N.H.; Mohd Esa, N.; Ithnin, H.; Md Akim, A.; Saad, N.; Pandurangan, A.K. Preventive inositol hexaphosphate extracted from rice bran inhibits colorectal cancer through involvement of Wnt $/ \beta$-catenin and COX-2 pathways. BioMed Res. Int. 2013, 2013, 10. [CrossRef]

20. Higuchi, M. Antioxidant properties of wheat bran against oxidative stress. In Wheat and Rice in Disease Prevention and Health: Benefits, Risks and Mechanisms of Whole Grains in Health Promotion; Elsevier Inc.: Amsterdam, The Netherlands, 2014; pp. 181-199. ISBN 9780124017160.

21. Barahuie, F.; Dorniani, D.; Bullo, S.; Sivapragasam, G.; Hussein, M.Z.; Pandurangan, A.K.; Palanisamy, A.; Mohd Esa, N. Sustained release of anticancer agent phytic acid from its chitosan-coated magnetic nanoparticles for drug-delivery system. Int. J. Nanomed. 2017, 12, 2361-2372. [CrossRef]

22. Tan, B.L.; Norhaizan, M.; Chan, L.C. An intrinsic mitochondrial pathway is required for phytic acid-chitosan-iron oxide nanocomposite (Phy-CS-MNP) to induce $\mathrm{G}_{0} / \mathrm{G}_{1}$ cell cycle arrest and apoptosis in the human colorectal cancer (HT-29) cell line. Pharmaceutics 2018, 10, 198. [CrossRef] [PubMed]

23. Erhirhie, E.O.; Ihekwereme, C.P.; Ilodigwe, E.E. Advances in acute toxicity testing: Strengths, weaknesses and regulatory acceptance. Interdiscip. Toxicol. 2018, 11, 5-12. [CrossRef] [PubMed]

24. OECD. Test, no. 423: Acute oral toxicity-Acute toxic class method. In OECD Guidelines for the Testing of Chemicals; OECD Publishing: Paris, France, 2002.

25. Wada, S.; Yue, L.; Tazawa, K.; Furuta, I.; Nagae, H.; Takemori, S.; Minamimura, T. New local hyperthermia using dextran magnetite complex (DM) for oral cavity: Experimental study in normal hamster tongue. Oral Dis. 2001, 7, 192-195. [CrossRef] [PubMed]

26. Ahmad, S.; Nurul, S.; Hazilawati, H.; Mohd, R.S.; Hanif, F.; Mohd, R.; Noordin, M.M.; Norhaizan, E. Subacute oral toxicity assesment of ethanol extract of Mariposa christia vespertilionis leaves in male Sprague dawley rats. Toxicol. Res. 2018, 34, 85-95.

27. Kumari, M.; Rajak, S.; Singh, S.P.; Murty, U.S.N.; Mahboob, M.; Grover, P.; Rahman, M.F. Biochemical alterations induced by acute oral doses of iron oxide nanoparticles in Wistar rats. Drug Chem. Toxicol. 2012, 36, 1-10. [CrossRef] [PubMed]

28. Ewis, R.I.W.L.; Illington, R.I.B.; Ebryune, E.R.I.C.D.; Amer, A.R.G.; Ang, B.L. Recognition of adverse and nonadverse effects in toxicity studies. Toxicol. Pathol. 2002, 30, 66-74.

29. Fields, D.; Higgins, P. Physiological mechanism impacting weight regulation. In Handbook of Childhood and Adolescent Obesity; Jelalian, E., Steele, R.G., Eds.; Springer: Boston, MA, USA, 2008; pp. 109-126.

30. Michael, B.; Yano, B.; Sellers, R.S.; Perry, R.; Morton, D.; Roome, N.; Johnson, J.K.J.; Schafer, K. Evaluation of organ weights for rodent and non-rodent toxicity studies: A review of regulatory guidelines and a survey of current practices. Toxicol. Pathol. 2007, 35, 742-750. [CrossRef] [PubMed]

31. Mahmudul, K.; Tamanna, N.; Haque, A. Biochemical and histopathological profiling of Wistar rat treated with Brassica napus as a supplementary feed. Food Sci. Hum. Wellness 2018, 7, 77-82.

32. Webber, M.; Krishnan, A.; Thomas, N.G.; Cheung, B.M.Y. Association between serum alkaline phosphatase and C-reactive protein in the United States national health and nutrition examination survey 2005-2006. Clin. Chem. Lab. Med. 2010, 48, 167-173. [CrossRef]

33. Higgins, C. Urea and the Clinical Value of Measuring Blood Urea Concentration. Available online: https: //acutecaretesting.org/en/articles/urea-and-the-clinical-value-of-measuring-blood-urea-concentration (accessed on 23 April 2019).

34. Qu, J.; Liu, G.; Wang, Y.; Hong, R. Preparation of $\mathrm{Fe}_{3} \mathrm{O}_{4}-\mathrm{Chitosan}$ nanoparticles used for hyperthermia. Adv. Powder Technol. 2010, 21, 461-467. [CrossRef]

(C) 2019 by the authors. Licensee MDPI, Basel, Switzerland. This article is an open access article distributed under the terms and conditions of the Creative Commons Attribution (CC BY) license (http://creativecommons.org/licenses/by/4.0/). 